\title{
Cytochrome P450 oxidoreductase genetic polymorphism and pantoprazole pharmacokinetics in healthy volunteers
}

\section{Polimorfizm genu oksydoreduktazy cytochromu P450 a farmakokinetyka pantoprazolu u zdrowych ochotników}

\author{
Mateusz Kurzawski ${ }^{1}$, Barbara Gawrońska-Szklarz², Urszula Adamiak-Giera², Elżbieta Wyska², \\ Marek Droździk¹, Sylwia Szeląg-Pieniek ${ }^{1 凶}$

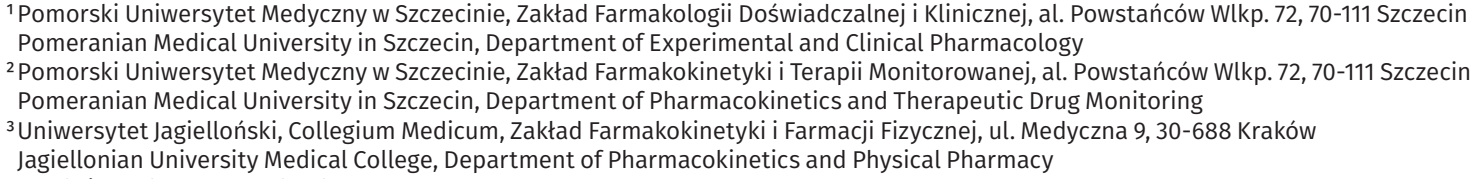

\begin{abstract}
Introduction: It has recently been demonstrated that $\mathrm{CYP}_{2} \mathrm{C} 19$ activity may be influenced not only by $\mathrm{CYP}_{2} \mathrm{C} 19$ polymorphism, but also cytochrome $\mathrm{P} 450$ oxidoreductase (POR) protein abundance in human liver microsomes. The human POR gene is highly polymorphic and a common $P O R^{*} 28$ allele is associated with increased POR activity, which may result in increased CYP P450 activity (including CYP2C19).

The aim of the current study was to evaluate the association between $P O R$ and $C_{Y P} C_{19}$ polymorphisms and $\mathrm{CYP}_{2} \mathrm{C}_{19}$ substrate pharmacokinetics, i.e. pantoprazole, in Polish Caucasian healthy volunteers.

Materials and methods: The study enrolled 30 subjects, genotyped for rs4244285 $\left(681 \mathrm{G}>\mathrm{A}, \mathrm{CYP} 2 \mathrm{C}_{19}{ }^{*}\right)$ ), rs12248560 (-806C $>\mathrm{T}$, CYP2C19*17) and rs1057868 (31696C >T, POR ${ }^{*} 28$ ). Pantoprazole
\end{abstract}

concentration in plasma was determined by validated highperformance liquid-chromatography method $1 \mathrm{~h}, 2 \mathrm{~h}, 3 \mathrm{~h}, 4 \mathrm{~h}, 6 \mathrm{~h}$ and $8 \mathrm{~h}$ after a single oral $40 \mathrm{mg}$ dose of the drug.

Results: No significant differences in the drug concentrations between $P O R^{*} 1 /{ }^{*} 1, \mathrm{POR}^{*} 1 /{ }^{*} 28$ and $P O R^{*} 28 /{ }^{*} 28$ carriers were observed. Multivariate analysis revealed that the $C Y P_{2} C_{19}$ genotype significantly influenced all the investigated pharmacokinetic parameters $(\mathrm{p}<0.05)$, while the POR genotype was not associated with any of the parameters.

Conclusions: The results of the current study suggest that $P O R$ polymorphism does not significantly influence pantoprazole pharmacokinetics.

Keywords: pantoprazole; pharmacokinetics; pharmacogenetics; POR; cytochrome P450 oxidoreductase.

\begin{abstract}
ABSTRAKT
Wstęp: Genetycznie uwarunkowana aktywność enzymów metabolizujących leki może mieć znaczenie dla bezpieczeństwa i skuteczności leczenia. We wcześniejszych badaniach wykazano, że na aktywność enzymatyczną CYP2C19 może wpływać nie tylko polimorfizm genu kodującego ten cytochrom, lecz także zawartość reduktazy cytochromu P450 (POR) w mikrosomach ludzkich hepatocytów. Ludzki gen POR wykazuje dużą zmienność, a allel $P O R^{*} 28$ jest związany ze zwiększoną aktywnością reduktazy, co w konsekwencji może prowadzić do zwiększonej aktywności układu CYP P450, w tym enzymu CYP2C19.

Celem badania było określenie związku pomiędzy polimorfizmem genu POR a parametrami farmakokinetycznymi pantoprazolu, substratu CYP2C19 w grupie zdrowych ochotników. W analizie uwzględniono także warianty genu CYP2C19.

Materiały i metody: U 30 osób, u których wykonano badanie pod kątem występowania jednonukleotydowych polimorfizmów:
\end{abstract}

rs4244285 (681G>A, CYP2C19*2), rs12248560 (-806C > T, CYP2C19*17) oraz rs1057868 (31696C >T, POR ${ }^{*} 28$ ). Stężenia pantoprazolu w osoczu zmierzono metodą wysokosprawnej chromatografii cieczowej w ciągu 8 godz. od przyjęcia pojedynczej doustnej dawki leku (40 mg).

Wyniki: Nie stwierdzono istotnych różnic w stężeniu pantoprazolu pomiędzy osobami o różnych genotypach POR $\left({ }^{*} 1{ }^{*}{ }_{1}\right.$, $\left.*_{1} /{ }^{*} 28 \mathrm{i} *_{2} 8 /{ }^{*} 28\right)$. Analiza wieloczynnikowa wykazała, że genotyp CYP2C19 istotnie wpływał na wartość wszystkich analizowanych parametrów farmakokinetycznych $(\mathrm{p}<0.05)$, podczas gdy genotyp POR nie był istotnie związany z żadnym z nich. Wnioski: Wyniki badania wskazują, że polimorfizm genu $P O R$ nie wpływa istotnie na farmakokinetykę pantoprazolu. Słowa kluczowe: pantoprazol; farmakokinetyka; farmakogenetyka; POR; oksydoreduktaza cytochromu P450. 


\section{INTRODUCTION}

Recently, Shirasaka et al. demonstrated, assaying human liver microsomes (S)-mephenytoin hydroxylase activity, that interindividual variability in $\mathrm{CYP} 2 \mathrm{C} 19$ activity was due to differences in $\mathrm{CYP} 2 \mathrm{C} 19$ protein content determined by genotypes (decreasing from $C Y P_{2} C_{19} *_{17} /{ }^{*} 17$ to ${ }^{*} /{ }^{*} 2$ ) and cytochrome P450 oxidoreductase (POR) protein abundance in human liver microsomes [1]. CYP2C19 plays an important role in the metabolism of many medications, e.g. proton pump inhibitors, antiplatelet drugs, antiepileptics, and antidepressants. Its function can be partially determined by $C \mathrm{P}_{2} \mathrm{C}_{19}$ polymorphism. The available studies demonstrated that individuals homozygous for the inactive $\mathrm{CYP}_{2} \mathrm{C}_{19}{ }^{*} 2$ allele, resulting in a splicing defect, are phenotypically poor metabolizers of CYP2C19 substrates. Likewise, carriers of the $\mathrm{CYP}_{2} \mathrm{C}_{19}{ }^{*} 3$ allele (premature stop codon), present in Asian populations, are categorized to $\mathrm{CYP}_{2} \mathrm{C} 19$ poor metabolizers [2]. Conversely, the $\mathrm{CYP}_{2} \mathrm{C}_{1}{ }^{*} 17$ variant allele, harbouring $-806 \mathrm{C}>\mathrm{T}$ substitution in the promoter region, is associated with an increased, ultra-rapid enzymatic activity of $\mathrm{CYP}_{2} \mathrm{C} 19$, probably due to its affect on the binding of transcription factors that enhance gene transcription [3]. Although CYP2C19 activity in liver microsomes from carriers of at least one $C Y P 2 C 1{ }^{*} 17$ allele did not differ significantly from wild-type homozygous livers, a trend towards increased enzymatic rate in $\mathrm{CYP}_{2} \mathrm{C}_{19}{ }^{*} 17$ livers was noted [4]. Chiba et al. estimated in vivo inter-individual variability, i.e. coefficient of variation' in hepatic intrinsic clearance in CYP2C19 poor metabolizers $\left(\mathrm{CYP}_{2} \mathrm{C}_{19}{ }^{*}{ }_{2} /{ }^{*} 2, \mathrm{CYP} 2 \mathrm{C}_{1}{ }^{*} 3{ }^{*}{ }^{*} 3\right.$ or $\left.\mathrm{CYP} 2 \mathrm{C}_{19}{ }^{*}{ }^{2}{ }^{*} 3\right)$ at $25.8 \%$, in extensive metabolizers $\left(C Y P_{2} C_{1}{ }^{*} 1{ }^{*}{ }^{*}\right)$ at $66.0 \%$, intermediate metabolizers $\left(\mathrm{CYP}_{2} \mathrm{C}_{19}{ }^{*} 1{ }^{*}{ }^{*} 2\right.$ or $\left.{ }^{*} 3\right)$ at $55.8 \%$, and ultra-rapid metabolizers $\left.\left(C Y P_{2} C_{19}{ }^{*} 17\right)^{*} 17\right)$ at $6.8 \%$ [2].

One of the factors possibly interfering with CYPs activity is POR, a flavoprotein which as an electron donor plays a key role in the catalytic rate of CYPs. The human POR gene is highly polymorphic. The most common polymorphism, i.e. $P O R^{*} 28$ is characterized by a change of a single amino acid from alanine to valine $(\mathrm{A503} \mathrm{V})$ [5]. The $\mathrm{POR}^{*} 28$ allele has been shown to be functional, and is associated with increased POR activity, leading to increased CYP $\mathrm{P}_{450}$ activity (CYP3A4 and $3 \mathrm{~A}_{5}$, CYP2C19) [6, 7]. As for the interaction between POR and CYP2C19 polymorphisms, only one study has been published. Saruwatari et al. reported that $\mathrm{CYP}_{2} \mathrm{C}_{19}$ and $\mathrm{POR}^{*} 28$ genotypes produced an impact on clobazam and $\mathrm{N}$-desmethylclobazam clearance in a Japanese population [8]. However, there is no available information on the association of $P R^{*} 28$ and $C Y P_{2} C_{19}$ polymorphisms with the pharmacokinetics of $\mathrm{CYP}_{2} \mathrm{C} 19$ substrates in Caucasians. Both populations are different in terms of the frequency of $\mathrm{CYP}_{2} \mathrm{C}_{19}{ }^{*} 3$ polymorphism, which is found in $8.8 \%$ of Asians and less than $0.1 \%$ in Caucasians, and to a lesser range for $\mathrm{CYP}_{2} \mathrm{C}_{9}$ 2, i.e. $28.6 \%$ and $12-16 \%$, respectively [9]. As for the CYP2C19*17 allele, it is found in $18-28 \%$ of subjects of Caucasian ancestry and in $0.3-4 \%$ of Asian individuals [10].

The aim of this study was to evaluate the association between POR and CYP2C19 polymorphisms and CYP2C19 substrate pharmacokinetics, i.e. pantoprazole, in Polish Caucasian healthy subjects.

\section{MATERIALS AND METHODS}

The study enrolled 30 healthy volunteers ( 15 males/ 15 females), Polish Caucasians, aged 21-26 years, weighing 52-90 kg. Six individuals for each of the following $C_{Y P} C_{19}$ genotypes were recruited: $C Y P_{2} C 1{ }^{*} 1 /{ }^{*} 1, C Y P_{2} C 19^{*} 1 /{ }^{*} 2, C Y P_{2} C 19^{*} 1 /{ }^{*} 17$, $\mathrm{CYP}_{2} \mathrm{C}_{19}{ }^{*} 2{ }^{*}{ }^{*}$ 7, and $\mathrm{CYP} 2 \mathrm{C}_{19}{ }^{*} 17 /{ }^{*} 17$ (detailed subject characteristics were previously published in ref. [11]). CYP2C19*2/*2 individuals were excluded from the current analysis (two subjects).

Genotyping for rs4244285 (681G>A, CYP2C19*2), rs12248560 $\left(-806 \mathrm{C}>\mathrm{T}, \mathrm{CYP} 2 \mathrm{C}_{19}{ }^{*} 17\right)$ and $\mathrm{rs} 1057868$ (31696C $\left.>\mathrm{T}, \mathrm{POR}^{*} 28\right)$ SNPs was performed in all study subjects, using genomic DNA isolated from whole blood samples (GeneMATRIX Quick Blood DNA Purification Kit, EURx, Poland). Allelic discrimination TaqMan assays (Assay IDs: C_25986767_70, C_469857_10, C_-_8890131_30, Life Technologies, USA) and 7500 FAST RealTime PCR System (Applied Biosystems) were used for genotype determination.

Pantoprazole concentration in plasma was determined by a validated high-performance liquid-chromatography method with ultraviolet detection following solid phase extraction after a single oral $40 \mathrm{mg}$ dose of the drug. Blood samples were drawn before drug administration, and then at $1 \mathrm{~h}, 2 \mathrm{~h}, 3 \mathrm{~h}, 4 \mathrm{~h}, 6 \mathrm{~h}$ and $8 \mathrm{~h}$ post-dose. The analytical procedures were previously published in detail by Gawrońska-Szklarz et al. [11].

The pharmacokinetic parameters of pantoprazole, i.e. clearance/F ( F - fraction of a dose absorbed), distribution volume, half-life, mean residence time, time to maximum concentration and maximum concentration were derived by noncompartmental analysis using Phoenix WinNonlin 6.2 (Pharsight Corporation, Mountain View, USA). For each individual the terminal elimination rate constant was determined by log-linear regression of the terminal phase of the plasma concentration-time curve. The area under the concentration-time curve was determined by the linear trapezoidal rule from time zero to the time of the last observed concentration [12]. Differences between individuals with variant genotypes were evaluated using Student t-test and log-transformed values of pharmacokinetic parameters. Additionally, multivariate analysis of variance (MANOVA) with both $C Y P_{2} C_{19}$ and $P O R$ genotypes as variables was performed. The level of significance was set at 0.05 .

The study protocol was approved by the local Ethical Committee at the Pomeranian Medical University in Szczecin (Poland). All performed procedures were in accordance with the institutional and/or national research committee, and with the 1964 Helsinki declaration and its later amendments or comparable ethical standards. Informed consent was obtained from all participants included in the study. 


\section{RESULTS}

The mean pantoprazole plasma concentrations in the evaluated subjects with different $P O R$ genotypes are presented in Figure 1. No significant differences in the drug concentrations between $P O R^{*} 1 /{ }^{*} 1, P O R^{*} 1 /{ }^{*} 28$ and $P O R^{*} 28 / *_{2} 8$ carriers were observed. Likewise, the values of the pharmacokinetic parameters did not differ significantly in both POR groups (Table 1).

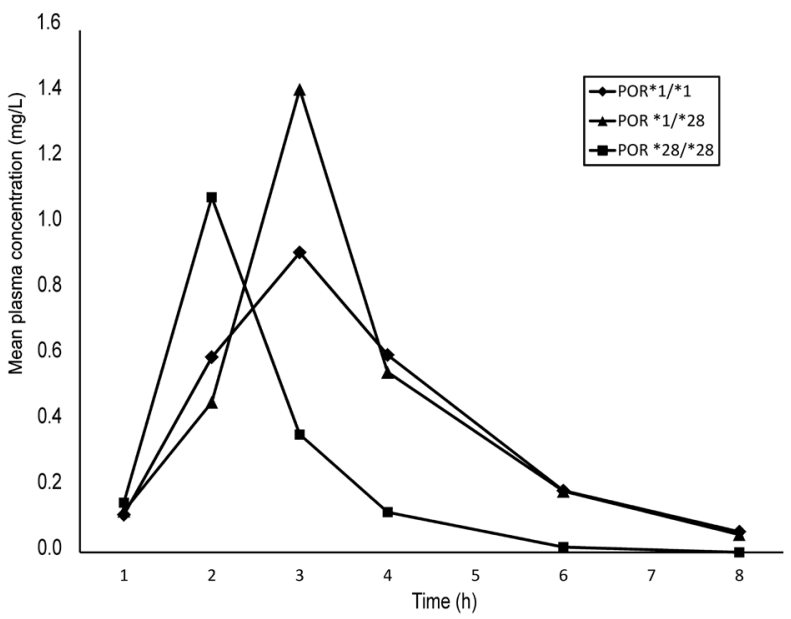

FIGURE 1. Mean plasma concentration-time profiles in individuals with different $P O R$ genotypes after administration of $40 \mathrm{mg}$ pantoprazole as a single oral dose. POR polymorphism did not significantly affect the drug concentrations within 8 hours after administration

TABLE 1. Pharmacokinetic parameters of pantoprazole in subjects stratified according to $P O R^{\star} 28$ polymorphism

\begin{tabular}{lccc} 
Parameter & $\begin{array}{c}P O R^{*} 1 /{ }^{*} 1 \\
(\mathbf{n}=18)\end{array}$ & $\begin{array}{c}P O R^{*} 28 \text { carriers } \\
(\mathbf{n}=12)\end{array}$ & $\mathbf{p}$ \\
\hline$\lambda_{\mathrm{z}}\left(\mathrm{h}^{-1}\right)$ & $0.619 \pm 0.273$ & $0.568 \pm 0.185$ & 0.641 \\
\hline $\mathrm{t}_{1 / 2}(\mathrm{~h})$ & $1.274 \pm 0.424$ & $1.330 \pm 0.376$ & 0.641 \\
\hline $\mathrm{t}_{\max }(\mathrm{h})$ & $2.583 \pm 0.691$ & $2.604 \pm 0.559$ & 0.848 \\
\hline $\mathrm{C}_{\max }(\mathrm{mg} / \mathrm{L})$ & $1.588 \pm 0.514$ & $1.715 \pm 0.560$ & 0.539 \\
\hline $\mathrm{AUC}(\mathrm{mg} \cdot \mathrm{h} / \mathrm{L})$ & $2.757 \pm 1.076$ & $2.799 \pm 1.086$ & 0.906 \\
\hline $\mathrm{V}_{\mathrm{z}} / \mathrm{F}(\mathrm{L})$ & $26.491 \pm 7.556$ & $27.109 \pm 6.880$ & 0.732 \\
\hline $\mathrm{CL} / \mathrm{F}(\mathrm{L} / \mathrm{h})$ & $16.267 \pm 8.049$ & $15.817 \pm 7.755$ & 0.869 \\
\hline $\mathrm{MRT}(\mathrm{h})$ & $3.456 \pm 0.704$ & $3.456 \pm 0.658$ & 0.976 \\
\hline
\end{tabular}

Results presented as mean $\pm S D$; $p$ values calculated by means of the Student t-test, using log-transformed values; $\lambda$ - terminal elimination rate constant; $t_{\text {. }}$ half-life; $t_{\max }$ - time to maximum concentration; $C_{\max }$ - maximum concentration; $A U C$ - the area under the concentration-time curve; $V_{2} / F$ - distribution volume; $\mathrm{CL} / \mathrm{F}$ - clearance/ $\mathrm{F}$ ( $\mathrm{F}$ - fraction of a dose absorbed); MRT - mean residence time

\section{DISCUSSION}

It was documented that the pharmacokinetics of some CYP2C19 substrates, including pantoprazole, as well as the clinical outcome of peptic ulcer disease and depression treatment were associated with $\mathrm{CYP}_{2} \mathrm{C}_{19}$ activity and $\mathrm{CYP}_{2} \mathrm{C}_{19}$ gene polymorphism $[3,11,13,14,15,16]$. Some recent findings of Karaca et al. suggest that $C Y P_{2} C 19$ polymorphism affects only pantoprazole pharmacokinetics, but not Helicobacter pylori eradication rate in a Turkish population [17]. However, it should be pointed out that the effects of antibacterial management depend not only on drug concentrations, but also regional bacterial antibiotic resistance.

POR activity, and assuming the functional role of $\mathrm{POR}^{*} 28$ variant allele, and also its polymorphism, can be one of the factors regulating the activity of various CYPs, mainly $\mathrm{CYP}_{3} \mathrm{~A}_{4}$, CYP2B6, with a single report on CYP2C19. However, the results are contradictory, and can be partly explained by the ethnicity of studied populations $[6,7,18,19,20]$. Our previous data demonstrated that $P O R^{*} 28$ polymorphism did not affect the pharmacokinetics of tacrolimus, a substrate for $\mathrm{CYP}_{3} \mathrm{~A}_{4}$, in Polish-Caucasian kidney transplant patients [21].

The $P O R^{*} 28$ allele has been shown to be functional, resulting in increased POR activity, and then leading to increased CYP P450 activity (CYP3A4 and 3A5, CYP2C19) [6, 7]. However, an in vitro report on $\mathrm{POR}^{*} 28$ variant activity demonstrated only a mild (113\%) increase in CYP2C19 catalytic activity, using EOMCC (a fluorogenic non-drug agent) as a substrate [5].

The available clinical information on an association between $\mathrm{POR}^{*} 28$ genotype and $\mathrm{CY} \mathrm{P}_{2} \mathrm{C} 19$ activity has been reported only by Saruwatari et al. so far. The authors demonstrated that clobazam (CYP2C19 substrate) clearance was significantly lower by $18 \%$ in $\mathrm{CYP}_{2} \mathrm{C} 19$ poor metabolizers in comparison with homozygous extensive metabolizers among epileptic patients of Japanese ancestry. Increased clobazam clearance (by $44 \%$ ) in individuals homozygous for $P^{*}{ }^{*} 28$ allele compared to $P O R^{*} 28$ non-carriers was also observed [8]. However, the patients of the abovementioned study were co-medicated with phenobarbital, phenytoin and zonisamide, which significantly affected clobazam clearance, and thus could also have impacted the observed pharmacogenetic-pharmacokinetic interactions.

Conversely, our in vivo observations in healthy Caucasian volunteers did not demonstrate a significant impact of the POR polymorphism on pantoprazole pharmacokinetics (a probe drug for CYP2C19 activity), as only $\mathrm{CYP}_{2} \mathrm{C}_{19}$ genetic status was found to significantly affect the drug pharmacokinetics. The current results support the in vitro observations of Agraval et al., who documented only a weak relationship between $\mathrm{POR}^{*} 28(\mathrm{A503V})$ polymorphism and $\mathrm{CYP}_{2} \mathrm{C} 19$ activity in vitro, detecting $113 \%$ of wild-type CYP2C19 activity in the case of the $503 \mathrm{~V}$ variant expressed in E. coli [6]. The differences between two clinical observations may stem from known interethnic differences in allelic distribution, especially for the $C Y P_{2} C_{19}$ gene. Similarly, in another study from a Polish population an association between $\mathrm{POR}^{*} 28$ polymorphism and CYPA4 substrate tacrolimus pharmacokinetics was not found [21]. It should also be noted that a relationship between CYP2C19 activity, CYP2C19 polymorphism and POR protein content in human liver microsomes was revealed [1]. Those findings suggest that POR protein abundance in liver microsomes may be a better predictor of POR activity than the studied POR polymorphism. However, in the case of POR the situation seems relatively complex. The potential confounders list includes not only possible 
genetic variants of the CYP isoenzymes for which POR is an obligatory co-enzyme, but also cellular flavin content of the POR flavoprotein (e.g. in hepatocytes). The latter factors may also explain discrepancies observed in clinical studies.

\section{CONCLUSIONS}

A direct measurement of POR activity would be the best measure of enzymatic function, but along with protein content measurement is not feasible in clinical practice. Further clinical studies are needed to finally define the role of $P O R$ polymorphism in the regulation of $\mathrm{CYP}_{2} \mathrm{C} 19$ activity. Finally, the results of the current study suggests that, in contrast to $\mathrm{CYP} 2 \mathrm{C} 19$ variants, POR genetic polymorphism does not significantly influence pantoprazole pharmacokinetics.

\section{REFERENCES}

1. Shirasaka Y, Chaudhry AS, McDonald M, Prasad B, Wong T, Calamia JC, et al. Interindividual variability of CYP2C19-catalyzed drug metabolism due to differences in gene diplotypes and cytochrome P450 oxidoreductase content. Pharmacogenomics J 2016;16(4):375-87. doi: 10.1038/tpj.2015.58.

2. Chiba K, Shimizu K, Kato M, Nishibayashi T, Terada K, Izumo N, et al. Prediction of inter-individual variability in the pharmacokinetics of CYP2C19 substrates in humans. Drug Metab Pharmacokinet 2014;29(5):379-86. doi.org/10.2133/dmpk.DMPK-13-RG-137.

3. Sim SC, Risinger C, Dahl ML, Aklillu E, Christensen M, Bertilsson L, et al. A common novel CYP2C19 gene variant causes ultrarapid drug metabolism relevant for the drug response to proton pump inhibitors and antidepressants. Clin Pharmacol Ther 2006;79(1):103-13. doi: 10.1016/j. clpt.2005.10.002.

4. Sanford JC, Guo Y, Sadee W, Wang D. Regulatory polymorphisms in CYP2C19 affecting hepatic expression. Drug Metabol Drug Interact 2013;28(1):23-30. doi: 10.1515/dmdi-2012-0038.

5. Miller WL, Agrawal V, Sandee D, Tee MK, Huang N, Choi JH, et al. Consequences of POR mutations and polymorphisms. Mol Cell Endocrinol 2011;336(1-2):174-9. doi: 10.1016/j.mce.2010.10.022.

6. Agrawal V, Huang N, Miller WL. Pharmacogenetics of P450 oxidoreductase: effect of sequence variants on activities of CYP1A2 and CYP2C19. Pharmacogenet Genomics 2008;18(7):569-76. doi: 10.1097/ FPC.0b013e32830054ac.

7. Elens L, Hesselink DA, Bouamar R, Budde K, de Fijter JW, De Meyer M, et al. Impact of POR* 28 on the pharmacokinetics of tacrolimus and cyclosporine A in renal transplant patients. Ther Drug Monit 2014;36(1):71-9. doi: 10.1097/FTD.0b013e31829da6dd.

8. Saruwatari J, Ogusu N, Shimomasuda M, Nakashima H, Seo T, Tanikawa K, et al. Effects of CYP2C19 and P450 oxidoreductase polymorphisms on the population pharmacokinetics of clobazam and N-desmethylclobazam in japanese patients with epilepsy. Ther Drug Monit 2014;36(3):302-9. doi: 10.1097/FTD.0000000000000015.

9. Kurose K, Sugiyama E, Saito Y. Population differences in major functional polymorphisms of pharmacokinetics/pharmacodynamics-related genes in Eastern Asians and Europeans: implications in the clinical trials for novel drug development. Drug Metab Pharmacokinet 2012;27(1):9-54.

10. Pedersen RS, Brasch-Andersen C, Sim SC, Bergmann TK, Halling J, Petersen MS, et al. Linkage disequilibrium between the CYP2C19*17 allele and wildtype CYP2C8 and CYP2C9 alleles: identification of CYP2C haplotypes in healthy Nordic populations. Eur J Clin Pharmacol 2010;66(12):1199-205. doi: 10.1007/s00228-010-0864-8.

11. Gawrońska-Szklarz B, Adamiak-Giera U, Wyska E, Kurzawski M, Gornik W, Kaldonska M, et al. CYP2C19 polymorphism affects single-dose pharmacokinetics of oral pantoprazole in healthy volunteers. Eur J Clin Pharmacol 2012;68(9):1267-74. doi: 10.1007/s00228-012-1252-3.

12. Rowland M, Tozer TN. Clinical pharmacokinetics: concepts and applications. 2nd ed. Philadelphia: Lea and Febiger; 1989.

13. Román M, Ochoa D, Sánchez-Rojas SD, Talegón M, Prieto-Pérez R, Rivas Â, et al. Evaluation of the relationship between polymorphisms in CYP2C19 and the pharmacokinetics of omeprazole, pantoprazole and rabeprazole. Pharmacogenomics 2014;15:1893-901. doi: 10.2217/pgs.14.141.

14. Kurzawski M, Gawrońska-Szklarz B, Wrześniewska J, Siuda A, Starzyńska T, Droździk M. Effect of CYP2C19*17 gene variant on Helicobacter pylori eradication in peptic ulcer patients. Eur J Clin Pharmacol 2006;62(10):87780. doi: 10.1007/s00228-006-0183-2.

15. Furuta T, Sugimoto M, Shirai N. Individualized therapy for gastroesophageal reflux disease: potential impact of pharmacogenetic testing based on CYP2C19. Mol Diagn Ther 2012;16(4):223-4. doi: 10.2165/11634960000000000-00000.

16. Desta Z, Modak A, Nguyen PD, Lemler SM, Kurogi Y, Li L, et al. Rapid identification of the hepatic cytochrome P450 2C19 activity using a novel and noninvasive [13C]pantoprazole breath test. J Pharmacol Exp Ther 2009;329(1):297-305. doi: 10.1124/jpet.108.147751.

17. Karaca RO, Kalkisim S, Altinbas A, Kilincalp S, Yuksel I, Goktas MT, et al. Effects of genetic polymorphisms of cytochrome P450 enzymes and MDR1 transporter on pantoprazole metabolism and Helicobacter pylori eradication. Basic Clin Pharmacol Toxicol 2017;120(2):199-206. doi: 10.1111/ bcpt.12667.

18. Gao LC, Liu FQ, Yang L, Cheng L, Dai HY, Tao R, et al. The P450 oxidoreductase (POR) rs2868177 and cytochrome $\mathrm{P} 450$ (CYP) 2B6*6 polymorphisms contribute to the interindividual variability in human CYP2B6 activity. Eur J Clin Pharmacol 2016;72(10):1205-13. doi: 10.1007/s00228-016-2095-0.

19. Jannot AS, Vuillemin X, Etienne I, Buchler M, Hurault de Ligny B, Choukroun $\mathrm{G}$, et al. A lack of significant effect of $\mathrm{POR}^{*} 28$ allelic variant on tacrolimus exposure in kidney transplant recipients. Ther Drug Monit 2016;38(2):223-9. doi: 10.1097/FTD.0000000000000267.

20. Wei KK, Zhang LR. Interactions between CYP3A5*3 and POR*28 polymorphisms and lipid lowering response with atorvastatin. Clin Drug Investig 2015;35(9):583-91. doi: 10.1007/s40261-015-0317-3.

21. Kurzawski M, Malinowski D, Dziewanowski K, Droździk M. Impact of PPARA and POR polymorphisms on tacrolimus pharmacokinetics and new-onset diabetes in kidney transplant recipients. Pharmacogenet Genomics 2014;24(8):397-400. doi: 10.1097/FPC.0000000000000067. 